\title{
UMA PALAVRA INICIAL
}

número Especial de 2015, organizado por Inês Signorini e denominado Epistemologias da Pesquisa no Campo Aplicado dos Estudos da Língua(gem), inaugura o nosso compromisso de publicar quatro números a cada ano. O presente número, organizado por João Telles, intitula-se Learning Foreign Languages in Teletandem, completa o primeiro aniversário da edição de DELTA em quatro números anuais, dos quais, aqueles que tiverem editores convidados terão também um título específico.

Leila Barbara (Pontifícia Universidade Católica de São Paulo - PUC-SP)

lbarbara@uol.com.br 